\title{
The Extent of the Commitment of Islamic Banks Operating in the City of Hebron to Disclose Social Responsibility in the Published Financial Statements
}

\author{
Raed Abueid $P h D$ \\ Accounting Department \\ Faculty of Administrative and Economic Sciences \\ Al-Quds Open University, Hebron Branch, Palestine \\ E-mail: rabueid@qou.edu \\ Amani Tbakhi \\ Accounting Department \\ Faculty of Administrative and Economic Sciences \\ Al-Quds Open University, Hebron Branch, Palestine
}

\begin{abstract}
The research aimed to identify the extent of the commitment of Islamic banks in the city of Hebron to disclose social responsibility in the published financial statements, where a questionnaire was designed to answer the study questions. The questionnaires were distributed to all workers in Islamic banks operating in the city of Hebron, and the study concluded that the extent of The commitment of Islamic banks to disclose social responsibility in the financial data published in the city of Hebron was a high degree within its social responsibility, and the results also showed that there are obstacles when Islamic banks in the city of Hebron disclosed their activities in the areas of social responsibility, and the researchers have recommended the necessity of providing training courses for workers In Islamic banks, to introduce them to the strategy of disclosing social responsibility and its importance, as one of the strategies that contribute to achieving excellence in performance in general, and the need for the

Monetary Authority to issue special legislation, related to the adoption of Islamic banks to disclose their commitment to social responsibilities due to its implications for the performance of society.
\end{abstract}

Keywords: Disclosure, Islamic Banks, Financial Data, Hebron City.

\section{Introduction}

Islamic banks are financial and banking institutions with social and economic dimensions that "collect funds, invest and provide banking services in line with Shariah provisions: they are development institutions that seek to put money in its right paths" with a view to achieving social development in addition to achieving economic development. "Islamic banks came as a practical application of Aspects of the Islamic economy have a great responsibility that differs from the responsibility of traditional banks. This is because the Islamic economy is based on not dealing with usurious interest and consuming money unlawfully, while replacing transactions based on cooperation and interdependence in consideration of the interests of all society. On those values and principles, Islamic banks established their entity in pursuit of achieving Social and economic cooperation in addition to ridding society of dependency on traditional banks (Dahramoun, 2018).

In light of what is witnessing in recent years the return of interest in social and ethical issues at the level of the traditional economy from its various economic, financial and banking institutions' by incorporating some concepts that reflect the contemporary performance of their social role and that social responsibility is among the most prominent, it calls from Islamic banks the need to revive their social role towards different owners Its interests concerned with this, from its clients, human resources, society and the environment (Al-Qadi, 2010).

The term responsibility for social responsibility first appeared in 1923 when Sheldon indicated that the responsibility of any organization is first and foremost a social responsibility and that the survival and continuity of any organization is obligated to be committed to the performance of its social responsibility (Bitar, 2012). 
In the recent period of the twentieth century, there has been an increasing interest in the issue of social responsibility, and social accounting has received attention from international organizations and bodies as a source of information necessary to achieve sustainable development in the underdeveloped countries (Yahia'i 20II).

Based on the foregoing, the need arises to develop the accounting profession to include accounting and disclosure of social responsibility. In order to implement it, it was necessary for the administration to recognize the importance of social responsibility and then apply it and then disclose it through the financial reports prepared by the project management (Ayyash '2010).

In light of the above and given the importance of Islamic banks in social development, this research seeks to identify the extent of the commitment of Islamic banks to disclose social responsibility in the financial statements published in the city of Hebron.

\section{The study problem and its questions}

There is no doubt that the growing demand of various economic and financial institutions in general and traditional banks in particular 'to adopt the concept of social responsibility and other concepts that reflect the contemporary performance of the social role, imposes on Islamic banks the need to revive the performance of their social role that has been laid down for them since its foundation' and that along with the performance of its role The financial and its economic role 'Hence the problem of this study came to be presented in the following form:

To what extent is Islamic banks committed to disclosing social responsibility in the financial statements published in the city of Hebron? This main question is divided into the following sub-questions:

- Do Islamic banks in the city of Hebron contribute various activities within their social responsibility?

- Do Islamic banks disclose social responsibility activities in their published financial statements?

- What are the obstacles that prevent banks from disclosing their activities in the areas of social responsibility?

\section{The importance of studying}

The importance of this study stems from the fact that it clarifies the importance of the Palestinian Islamic banks 'awareness of the importance of implementing social responsibility in all its various fields. As well as the banks' awareness of the importance of measuring the costs of social responsibility and disclosing them in their financial reports and the benefits that can accrue to these banks as a result of their application and the disclosure of social responsibility. The study is important for the community to clarify what can be provided by the accounting and disclosure of social responsibility to the local community and the surrounding environment. Also, the study is important for banks and companies in various forms to activate the social dimension in their future plans in a way that contributes to achieving its goals and society's goals in development and achieves its continuity and the possibility of objective evaluation and comparison between different banks.

\section{Study Aims}

This study aims mainly to identify the extent of the commitment of Islamic banks to disclose social responsibility in the financial statements published in the city of Hebron. The following sub-goals fall under this goal:

- Explain what are social responsibility and its areas.

- Clarify the benefits and objectives of social responsibility to disclose the financial statements published in banks.

- Learn the principles and methods of disclosing social responsibility information in the financial statements.

- Knowing the extent of Islamic banks' awareness of the importance of social responsibility in its various fields.

- Determine the extent to which the bank management realizes the importance of measuring costs related to social responsibility.

- Knowing the extent of the Palestinian Islamic Banks administration's awareness of the importance of measuring the disclosure of social responsibility.

\section{Study hypotheses}

The first main hypothesis: The Islamic banks in the city of Hebron do not contribute to various activities within their social responsibility, and they derive from them:

- Islamic banks in the city of Hebron do not contribute to preserving the environment within their social responsibility. 
- Islamic banks in the city of Hebron do not contribute to the development of human resources within their social responsibility.

- Islamic banks in the city of Hebron do not contribute to improving the quality of banking services provided to their clients within their social responsibility.

- Islamic banks in the city of Hebron do not contribute to providing services to the local community within their social responsibility.

The second main hypothesis: Islamic banks in the city of Hebron do not disclose social responsibility activities in their published financial statements.

The third main hypothesis: There are no obstacles that prevent Islamic banks in the city of Hebron from disclosing their social responsibility activities in their published financial statements.

\section{Theoretical framework and previous studies \\ Introduction:}

The term Social Responsibility Definition is one of the concepts with historical roots extending for centuries, it is not a new concept dating back to the sixties of this century, it will no longer be confined to activities related to voluntary activities or donations but rather transcended it to become programs, plans and strategies and began to take The concept of social responsibility has broader dimensions, and interest in the concept of social responsibility has increased in the past decades by organizations of various and varied fields and activities of their work by governments and individuals alike to define the scope of responsibility, its dimensions and benefits and to develop appropriate legislative and regulatory frameworks for it (Abu Jami, 2016).

The first topic: The concept of social responsibility:

Social responsibility represents the activities and actions of the company in assuming responsibility resulting from the impact of its activities on society, so that its activities become compatible with the benefits of society and development and focus on ethical behavior, respect for government laws and regulations, and merge with the company's daily activities, it is a commitment to reduce any possible damage To affect society and avoid it, and to maximize the impact of its benefits in the long run. The dimensions of social responsibility for business sectors fall within legal, economic and moral responsibilities of a charitable nature, and are based on ethical considerations focused on the goals in the form of long-term commitments and initiatives of real business organizations to fulfill these obligations in a way that enhances its image in Society (Belal, 2010).

Hence, we offer the most important definitions of social responsibility, the most important of which are:

- The World Bank defined social responsibility as: the commitment to contribute to sustainable development by working with its employees and the local community as a whole to improve people's living standards in a manner that serves trade and development simultaneously (World Bank, 2009).

- Moon \& Matten also defined it as voluntary programs and strategies by companies that combine social and commercial value issues and an address seen as part of the company's social responsibility (Martinuzzi, 20II).

- Al-Houry (20I4) believes that social responsibility is a contract between the organization and the society in which the organization is committed to obtaining society's satisfaction and achieving its interests and is seen as the organization's commitment to society.

- The researcher defines social responsibility as: the commitment of organizations towards the societies in which they conduct their activities and work, through voluntary programs and strategies that combine social and commercial value issues to ensure the creation of an appropriate and sustainable work environment.

Social responsibility goals:

A- The objectives of social responsibility are generally represented in the following points:

- Demonstrate the ability to provide service consistently in accordance with customer requirements.

Increasing customer and employee satisfaction through effective system implementation. 
- Improving the capabilities and overall performance of work to meet the needs and expectations of its clients and other stakeholders.

- Develop and evaluate the effectiveness of measures taken by the institution to publicize and comply with policy and environmental and societal goals.

- Reducing and minimizing the risks that individuals may be exposed to in terms of safety and health, both at work and in society.

- Show to beneficiary groups that the Foundation's policies are consistent with the fundamental rights of work and society.

- Helping to develop a more effective dialogue with the beneficiary parties, with the assistance of the Foundation, to collect their various needs and aspirations to better manage and achieve a balance between social, economic and environmental performance (Saleh, 2015).

Activities and areas of social responsibility that the bank can adopt:

Social responsibility works to limit all activities and areas that the bank deals with, and there are other activities that are one of the basics of work and its requirements, and cannot be abandoned to ensure the progress of business such as defining the terms of reference for each person accurately and putting the right person in the right place for his qualifications and experiences, and among the most important activities and areas adopted by the bank To fulfill his social responsibility, the following (Al-Sharah, 2014):

A- Activities and areas of social responsibility towards shareholders

B- Activities and areas of the bank's social responsibility towards its employees

C- Activities and areas of the bank's social responsibility towards its clients

W - Activities and areas of the bank's social responsibility towards society

C- Activities and areas of social responsibility of Islamic banks towards society

Monetary and Social Responsibility Authority:

The Monetary Authority works to provide the appropriate climate for a decent life for the Palestinian citizen, through its purposeful and continuous effort to achieve financial stability in Palestine, and the efforts made to promote and enable sustainable development to improve the economic conditions of low-income social groups, the Monetary Authority has diversified the means it uses to achieve this by providing an opportunity to enhance the role of The banking system in the field of social responsibility, to alleviate poverty, enable and enhance the resilience of the Palestinian citizen and play its role in creating the appropriate banking climate to enhance the role of the banking system socially to carry out its role committed to community issues (Monetary Authority, 2014).

The second topic: Financial data:

Introduction:

Financial statements are considered a final product of accounting products, and a means of communicating information to beneficiaries, it is one of the means through which it can provide a continuous follow-up of all financial developments in the company, and for the financial statements to express fairly and clearly the true financial position of any institution, and ensure accurate information access Suitable for the categories used and helping them to make most decisions efficiently (Zouina, 20I4).

The concept of financial statements:

It is a set of financial statements of a company or institution, and it often contains information about income, balance sheet, profits, and cash flows, and these lists are activities that are applied by all companies and institutions and

\section{Previous studies:}

The first study: Zainab Al-Nabulsi study, 2018, entitled: "The impact of disclosure of social responsibility in annual financial reports on achieving a competitive advantage with Islamic banks operating in Jordan" 
This study aimed to identify the impact of social responsibility disclosure in annual financial reports on achieving a competitive advantage for Islamic banks operating in Jordan, and to achieve this goal a questionnaire was designed and distributed to a sample of the study that reached 87 respondents as follows: 30 employees from workers in Islamic banks operating in Jordan from various administrative levels and 57 clients from these banks. A descriptive analytical method and data analysis using the computer software spss were used. The study found that the disclosure of social responsibility in the annual financial reports related to (the field of workers and the field of protection The client, the field of the environment, and the field of society) works to achieve a competitive advantage for Islamic banks operating in Jordan, and the study recommended a set of recommendations, the most important of which are: the need to increase the interest of Islamic banks in social responsibility and disclosure and increase their financial allocations related to that, and the need to increase attention by the central bank to the requirements Disclosing social responsibility in the financial reports and encouraging all public joint stock companies to do so.

The second study: Mohamed Rahi study, 2017 entitled: "Disclosure of social responsibility and its impact on the performance of companies"

The study aimed to measure the impact of social responsibility areas on the company's financial performance in the short term, in addition to identifying the impact of social responsibility on the company's strategic performance, i.e. in the long term, as well as the study aimed at formulating a proposed model for accounting disclosure for social responsibility in all its fields (employee development, Environmental protection, public contributions, product quality), and to achieve the goals of the study, the study adopted the inductive and inductive approach, and the study sample was represented in one of the important industrial companies affiliated to the Iraqi Ministry of Industry, which is the General Company for Southern Cement, as this company was chosen in all its branches scattered in a number of governorates With the exception of two laboratories, investors, the study found that activities related to employee development are the activities that most affect the financial and strategic performance of the company, and the results of the study also showed the possibility for companies to disclose social responsibility in consolidated financial lists that include both economic and social activities, which provides financial statements expressive in a true and comprehensive manner On the company's activities, and the study recommended that a law be issued that binds all For companies in general, and industrial ones in particular, to disclose their costs and activities that they seek to implement in the future in their financial statements.

The third study: Al-Louh and Radi Study, 2016, entitled: "The extent to which banks operating in Palestine implement social responsibility: a comparative analytical study"

The aim of the research is to identify the extent to which banks operating in Palestine apply social responsibility by conducting a comparative analytical study, whereby the analytical and historical approach was used in the research, through the use of an intentional sample that dealt with banks operating in Palestine through reviewing their annual reports and determining the extent of their commitment to responsibility Social Affairs Throughout the years 2009-20I4, the most important results of the research were the existence of a disparity between banks in the application of social responsibility in terms of defining areas of social responsibility as well as allocating amounts to them, and the research also concluded that non-Palestinian banks operating in Palestine do not give sufficient attention to social responsibility in Palestine And that most of its interests belong to the mother country, and the most important recommendations of the research were the necessity of putting the areas of application of social responsibility in the banks 'plans and working to implement them, and that non-Palestinian banks should have a greater role in applying social responsibility, and that the Palestinian Monetary Authority should have a greater role in monitoring the extent of banks' application of social responsibility And to have an active role in coordinating efforts between banks.

The fourth study: a new study, Al-Azm, 2015, entitled: "Applying the reality of social responsibility in Jordanian banks and their impact on the competitive advantage from the viewpoint of workers in it."

The study aimed to identify the reality of the application of social responsibility in Jordanian banks, and their impact on their competitive advantage, and thus to identify the most important pillars on which Jordanian banks rely for the success of their application of social responsibility in order to achieve their goals and to serve the related parties with them, through an attempt to identify The extent of applying social responsibility towards nine dimensions, which are society, environment, auditors, employees, shareholders, government, suppliers, competitors, and towards minorities and people with special needs. In order to achieve this, the researchers selected a random sample of 170 workers from the study community, which is represented by employees Banks in various aspects of work and heads of banks working in directorates and branches, and a questionnaire was distributed to them, as it included 45 paragraphs on social responsibility and 16 paragraphs on competitive advantage, and the 
study reached the following results: An interest in social responsibility and the competitive advantage of banks, and a relationship between social responsibility and advantage Competitiveness of the banks, and the existence of a relationship between social responsibility and the competitive advantage of the managers and branches in question his head.

The Fifth Study: Rahmani Study, 2014, entitled: "The effect of excluding social responsibility on the financial performance of the economic institution"

This study was conducted in Algeria, at the National Institution of Works in Wells, on all of the 6,948 workers in the foundation. This study aimed to identify the impact of the company's commitment to the dimensions of responsibility.

\section{Study methodology}

In this study, a descriptive analytical approach was used that relies on the study of the phenomenon at present and as it is in reality, as it is the appropriate and best approach for such studies.

Study population: The study population consisted of all employees working in Islamic banks in the city of Hebron during the year 2019.

Study Sample: The sample consisted of (35) employees working in Islamic banks in the city of Hebron, who were chosen in a simple random manner, as shown in Table No. (I):

Table (I): Demographic sample characteristics

\begin{tabular}{|c|c|c|c|c|c|}
\hline & Total & Minus values & Percentage & Number & Variable number \\
\hline & & & & & Sex \\
\hline & \multirow[t]{2}{*}{35} & \multirow[t]{2}{*}{-} & $\% 71.4$ & 25 & Male \\
\hline & & & $\% 28.6$ & I0 & Female \\
\hline \multicolumn{6}{|c|}{ Job title } \\
\hline \multirow[t]{11}{*}{35} & & & $\% 20$ & 7 & Manager \\
\hline & & & $\%$ I7.I & 6 & Department Head \\
\hline & & & $\% 14.3$ & 5 & Accountant \\
\hline & & & $\% 48.6$ & 17 & Employee \\
\hline & & & & & Qualification \\
\hline & \multirow[t]{3}{*}{35} & - & $\% 80$ & 28 & Bachelor's degree \\
\hline & & & $\% 20$ & 7 & Master and above \\
\hline & & & & & Experience \\
\hline & \multirow[t]{3}{*}{35} & - & $8.6 \%$ & 3 & Less than 5 years \\
\hline & & & $\% 85.7$ & 30 & years $10-5$ \\
\hline & & & $\% 5.7$ & 2 & More than 10 years \\
\hline
\end{tabular}

Validity of the study tool: The study tool was built by referring to previous studies and the theoretical framework, and accordingly the questionnaire was finalized in its final form, then this tool was judged by distributing it to a group of experienced and specialized in the field, and the questionnaire was made up of two parts:

The first section: general information which is (gender, job title, educational qualification, experience)

The second section: It consists of three axes, namely:

The first axis: the contribution of banks to social responsibility activities within their activities (I-20)

The second axis: the disclosure of social responsibility activities (2I-28)

The third axis: impediments to disclosure of social responsibility activities (29-34) 
Reliability of the study tool: The research team calculated the stability in the Alpha Cronbach method, which ranged between $0.742-0.891$.

Study variables:

Independent variable: gender, job title, educational qualification, years of experience.

The dependent variable: The extent of the commitment of Islamic banks to disclose social responsibility in the financial statements published in the city of Hebron.

Study procedures:

After confirming the validity of the study tool, (35) questionnaires were distributed to employees in Islamic banks in the city of Hebron, the employees filled out the questionnaires, and the number of retrieved and analyzable questionnaires reached (35) questionnaires after collecting the study data, the researcher reviewed it in preparation for entering it into the computer, to work Statistical processing of the data, and it was entered by giving them specific numbers, where each level of approval degree was given a certain degree, and it was strongly disagree (I) degree, disagree (2) degree, neutral degree (3) degrees, degree of approval (4) (Degrees, with a degree strongly agree) (5) degrees where the higher the degree the extent of the commitment of Islamic banks to disclose social responsibility in the financial statements published in the city of Hebron.

Scale Correction: Correction keys were calculated as follows:

Table (2): Correction keys

\begin{tabular}{rr}
\hline Degree & Average arithmetic \\
\hline Low & $2.33-1.00$ \\
\hline Medium & $3.67-2.34$ \\
\hline High & $5.00-3.68$ \\
\hline
\end{tabular}

\section{Analysis of study results}

Answer the main question:

To what extent are Islamic banks committed to disclosing social responsibility in the financial statements published in the city of Hebron?

To answer the previous question, the mean and standard deviations were extracted to the extent of Islamic banks 'commitment to disclose social responsibility in the financial statements published in the city of Hebron, as shown in Table No. (3).

Table (3): Arithmetic averages and standard deviations for the extent of Islamic banks' commitment to disclose social responsibility in the financial statements published in the city of Hebron

\begin{tabular}{cccll}
\hline Degree & S.D & Mean & The Scale \\
\hline High & 0.170 & 4.013 & The extent of Islamic banks' commitment to disclose social responsibility in the financial statements \\
published in the city of Hebron
\end{tabular}

We note from the previous table and through the data provided that the extent of the commitment of Islamic banks to disclose social responsibility in the financial statements published in the city of Hebron was a high degree where the arithmetic average (4.013) with a standard deviation (0.170).

First major hypothesis analysis:

Islamic banks in the city of Hebron do not contribute to various activities within their social responsibility.

To answer the previous hypothesis, the following question was formulated: What is the extent of the Islamic banks' participation in the city of Hebron with various activities within its social responsibility? 
To answer the previous question, arithmetic averages and standard deviations were extracted to the extent of the Islamic banks' participation in the city of Hebron with various activities within their social responsibility, arranged according to importance, as shown in Table No. (4).

Table (4): Arithmetic averages and standard deviations for the extent of the Islamic banks' participation in the city of Hebron with various activities within their social responsibility, arranged according to importance

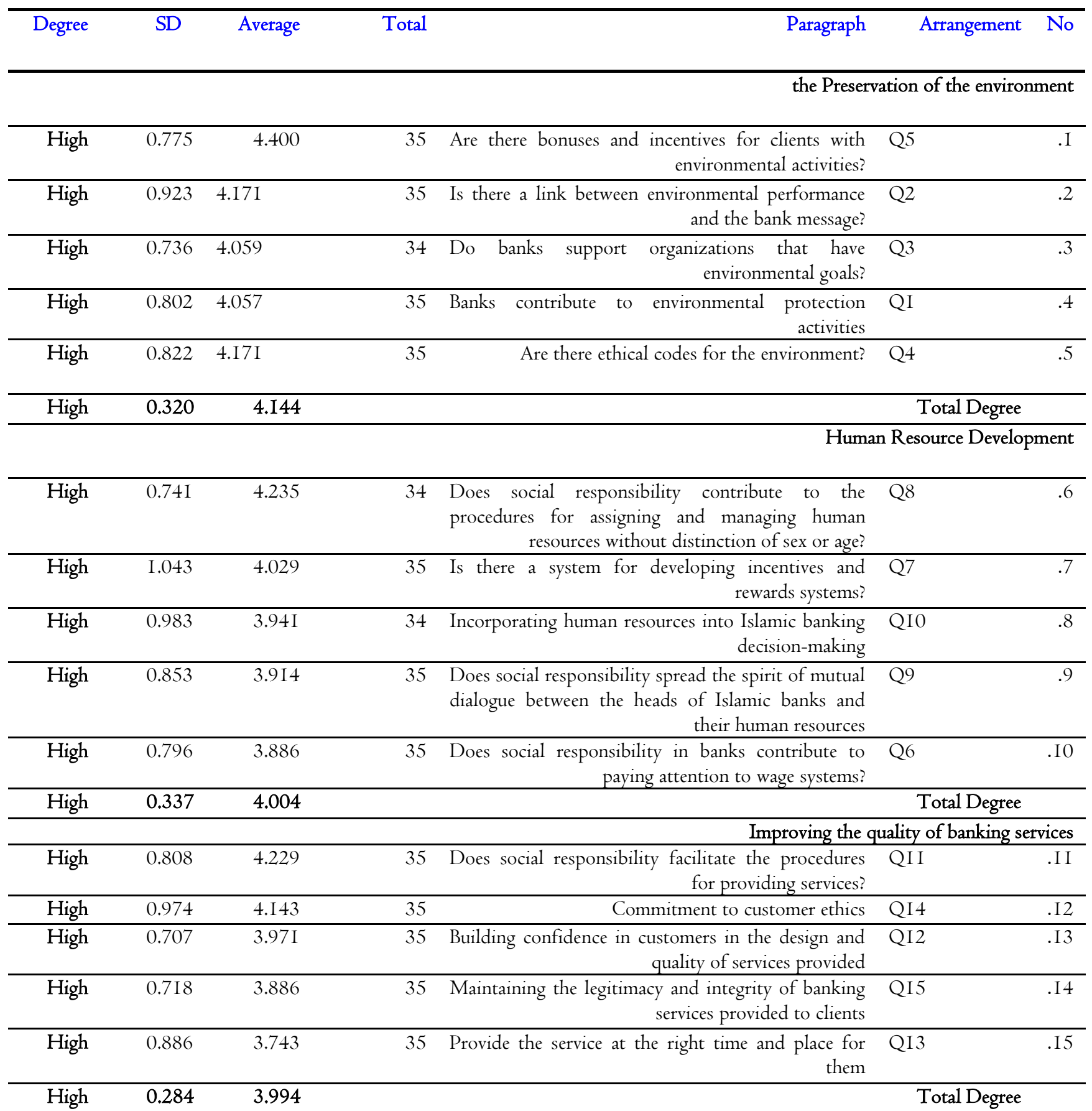

Providing services to the local community
High
0.933
4.200
35 There is a bank-specific strategy towards the mechanisms for determining CSR activities towards 
the local community

\begin{tabular}{|c|c|c|c|c|c|c|}
\hline High & 0.906 & 4.057 & 35 & $\begin{array}{l}\text { The bank's performance towards social } \\
\text { responsibility is reflected in the extent of the bank's } \\
\text { business in society }\end{array}$ & QI7 & .17 \\
\hline High & 0.887 & 3.914 & 35 & $\begin{array}{l}\text { The bank is based on multiple social activities to } \\
\text { increase the impact of social responsibility on society }\end{array}$ & QI8 & .18 \\
\hline High & 0.919 & 3.743 & 35 & $\begin{array}{l}\text { The bank is focusing on social activities to focus the } \\
\text { impact of social responsibility on specific groups }\end{array}$ & Q19 & .19 \\
\hline High & 0.957 & $3.7 \mathrm{I} 4$ & 35 & $\begin{array}{r}\text { The bank plays a societal role through responsibility } \\
\text { towards the community }\end{array}$ & Q16 & .20 \\
\hline High & 0.287 & 3.925 & & & \multicolumn{2}{|c|}{ Total Degree } \\
\hline High & 0.145 & 4.016 & & The total score for contribution to so & $1 \mathrm{re}$ & vities \\
\hline
\end{tabular}

It is clear from Table (4) that the degree of the contribution of Islamic banks in the city of Hebron to various activities within their social responsibility came at a high level with an arithmetic average (4.016) and a standard deviation (0.I45) and that the most prominent form of contribution to social responsibility activities was (preserving the environment) with an average of (4,I44) And a standard deviation (0.320) followed by (human resources development) with an average of (4.004) and a standard deviation (0.337), and in third place came (improving the quality of banking services) with an average of (3.994) and a standard deviation (0.284) and (providing services to the local community) came Average mean (3.925) and standard deviation (0.957)

The second hypothesis: Islamic banks in the city of Hebron do not disclose social responsibility activities in their published financial statements.

To answer the previous hypothesis, the following question was formulated: To what extent did Islamic banks in Hebron disclose social responsibility activities in its financial statements?

To answer the previous question, arithmetic averages and standard deviations were extracted to the extent of Islamic banks in Hebron disclosing social responsibility activities in their financial statements arranged according to importance, as shown in Table No. (5).

Table (5): Arithmetic averages and standard deviations for the extent of the disclosure by Islamic banks in the city of Hebron of social responsibility activities in their financial statements, arranged according to importance

\begin{tabular}{|c|c|c|c|c|c|c|}
\hline Degree & $\mathrm{SD}$ & Average & Total & Paragraph & Arrangement & No \\
\hline & & \multicolumn{5}{|c|}{ Islamic banks in Hebron disclose their social responsibility activities in their financial statements } \\
\hline High & 0.802 & 4.343 & 35 & $\begin{array}{l}\text { The bank provides descriptive (non-quantitative) } \\
\text { information about other social activities (costs and } \\
\text { benefits) that cannot be represented in monetary } \\
\text { values }\end{array}$ & Q28 & $.2 \mathrm{I}$ \\
\hline High & 0.893 & 4.286 & 35 & $\begin{array}{l}\text { The bank discloses in its published financial } \\
\text { statements the total costs it incurs to provide } \\
\text { training opportunities for university and institute } \\
\text { students }\end{array}$ & Q25 & .22 \\
\hline High & 0.887 & 4.086 & 35 & $\begin{array}{l}\text { In its published financial statements, the bank } \\
\text { allocates an item for the total costs of health care } \\
\text { for employees }\end{array}$ & Q24 & .23 \\
\hline High & 0.802 & 3.943 & 35 & $\begin{array}{l}\text { The bank shall disclose in its financial statements } \\
\text { the costs of disposal of waste that leads to }\end{array}$ & Q22 & .24 \\
\hline
\end{tabular}


environmental damage

\begin{tabular}{|c|c|c|c|c|c|c|}
\hline High & $0.8 \mathrm{I} 4$ & $3.94 \mathrm{I}$ & 34 & $\begin{array}{l}\text { The bank discloses in its financial statements the } \\
\text { value of donations and financial aid provided to } \\
\text { social organizations aimed at preserving the } \\
\text { environment. }\end{array}$ & Q2I & .25 \\
\hline High & $0.9 \mathrm{I} 2$ & 3.857 & 35 & $\begin{array}{l}\text { The bank discloses, in a special item, the amount } \\
\text { of income tax payable for annual profits }\end{array}$ & Q27 & .26 \\
\hline High & 0.964 & 3.800 & 35 & $\begin{array}{l}\text { In its published financial statements, the bank } \\
\text { discloses the costs it incurs to train employees and } \\
\text { acquire them with the necessary skills }\end{array}$ & Q23 & .27 \\
\hline High & 0.770 & $3.77 \mathrm{I}$ & 35 & $\begin{array}{l}\text { In its published financial statements, the bank } \\
\text { discloses the value of donations provided for health } \\
\text { care }\end{array}$ & Q26 & .28 \\
\hline High & 0.314 & 4.005 & & & & \\
\hline
\end{tabular}

It is clear from Table (5) that the degree of disclosure by Islamic banks in the city of Hebron for social responsibility activities in their financial statements came at a high degree with an average of (4.005) and a standard deviation (0.3I4) and that the most important paragraphs were paragraph (28) which states (the bank provides information Descriptive (non-quantitative) of other social activities (costs and benefits) that cannot be represented in monetary values) with an average mean (4.343) and a standard deviation (0.802), followed by paragraph (25) which states (the bank discloses in its published financial statements about the overall The costs you incur to provide training opportunities for university and institute students (mean) (4.286) and a standard deviation (0.893).

As for the less important paragraphs, it was paragraph No. (26) which states (the bank discloses in its published financial statements the value of donations provided for health care) with an average of (3.77I) and a standard deviation (0.770).

The third hypothesis: There are no obstacles that prevent Islamic banks in the city of Hebron from disclosing their social responsibility activities in their published financial statements.

To answer the previous hypothesis, the following question was formulated: What is the degree of obstacles to Islamic banks in Hebron to disclose social responsibility activities in its published financial statements?

To answer the previous question, arithmetic averages and standard deviations were extracted to the degree of obstacles that Islamic banks in the city of Hebron disclosed about social responsibility activities in their published financial statements arranged according to importance, as shown in Table No. (6).

Table (6): Arithmetic averages and standard deviations for the degree of obstacles to Islamic banks in Hebron to disclose social responsibility activities in its published financial statements, arranged according to importance

\begin{tabular}{|c|c|c|c|c|c|c|}
\hline Degree & $\mathrm{SD}$ & Average & Total & Paragraph & Arrangement & No \\
\hline \multicolumn{7}{|c|}{ Constraints for Islamic banks in Hebron to disclose social responsibility activities in its published financial statements } \\
\hline High & 0.796 & $4 . \mathrm{II} 4$ & 35 & $\begin{array}{l}\text { Difficulty measuring many items of social costs } \\
\text { and benefits }\end{array}$ & Q30 & .29 \\
\hline High & 0.832 & $4 . \mathrm{II} 4$ & 35 & $\begin{array}{l}\text { The management of the bank is concerned that } \\
\text { competing banks can use the disclosed } \\
\text { information on the bank's social responsibility }\end{array}$ & Q33 & .30 \\
\hline High & 0.904 & 4.029 & 34 & $\begin{array}{l}\text { Lack of legislation and laws obligated to disclose } \\
\text { social responsibility activities in the published }\end{array}$ & Q32 & $.3 \mathrm{I}$ \\
\hline EY & \multicolumn{4}{|c|}{ Copyright (C) CC-BY-NC 2020, CRIBFB | IIIBM } & & 52 \\
\hline
\end{tabular}


financial statements

\begin{tabular}{|c|c|c|c|c|c|c|}
\hline High & 0.785 & $3.97 \mathrm{I}$ & 35 & $\begin{array}{l}\text { Lack of awareness of the dimensions of the } \\
\text { concept of social responsibility accounting by the } \\
\text { bank's management }\end{array}$ & Q29 & .32 \\
\hline High & 0.906 & 3.943 & 35 & $\begin{array}{l}\text { Lack of educational programs to introduce } \\
\text { requirements of disclosure of social responsibility } \\
\text { in the published financial statements }\end{array}$ & Q3I & .33 \\
\hline High & 1.027 & 3.943 & 35 & $\begin{array}{l}\text { The bank does not have an accounting system that } \\
\text { meets the purposes of disclosing social } \\
\text { responsibility }\end{array}$ & Q34 & .34 \\
\hline High & $0.32 \mathrm{I}$ & 4.020 & & & & \\
\hline
\end{tabular}

It is clear from Table (6) that the degree of obstacles to Islamic banks in the city of Hebron to disclose social responsibility activities in its published financial statements came at a high level with an average of (3.020) and standard deviation (0.32I) and that the most important paragraphs were paragraph (30) which states (Difficulty measuring many items of social costs and benefits (with an average score of 4.II4) and a standard deviation (0.796), followed by paragraph (33) which states (the management of the bank is concerned about the ability of competing banks to use the disclosed information about the social responsibility of the bank) with an average score of (4.I I4) A standard deviation (0.832).

As for the less important paragraphs, it was paragraph No. (34) which states (the bank does not have an accounting system that meets the purposes of disclosing social responsibility) with an average of (3.943) and a standard deviation (I.027).

The fourth hypothesis: There is no statistically significant effect at the significance level $(0.05<=)$ of the contribution of Islamic banks in the city of Hebron to various activities within their social responsibility on the commitment of Islamic banks to disclose social responsibility in the financial statements.

To validate the previous hypothesis, Simple Regression analysis was used as shown in Table No. (7)

Table No. (7): Results of the simple regression analysis to test the effect of the Islamic banks 'contribution in the city of Hebron with various activities within their social responsibility on the Islamic banks' commitment to disclose social responsibility in the financial statements

\begin{tabular}{crrrrrr}
\hline Result & Sig. & Table & $\begin{array}{r}(T) \\
\text { value }\end{array}$ & $\begin{array}{r}\text { Calculated } \\
\text { value of } t\end{array}$ & R2 & R \\
\hline Rejected & 0.006 & 2.948 & II.028 & 3.17 I & $\% 20.8$ & 0.457 \\
\hline
\end{tabular}

The data provided in the previous table indicate that there is a statistically significant effect at the level (0.05) of the contribution of Islamic banks in the city of Hebron to various activities within their social responsibility on the commitment of Islamic banks to disclose social responsibility in the financial statements, where the calculated value of (T) was (II.028) It is greater than the value of the tabular $(\mathrm{T})$ of (2.948), and that the statistical significance was (0.006), which indicates that $(20.8 \%)$ of Islamic banks' disclosure of social responsibility in their financial statements is affected by the contribution to various activities, and thus rejects the null hypothesis and accepts the alternative hypothesis :

There is a statistically significant effect at the level of significance $(0.05 \square \leq)$ of the contribution of Islamic banks in the city of Hebron to various activities within their social responsibility on the obligation of Islamic banks to disclose social responsibility in the financial statements. 


\section{Discuss the results}

After conducting this study, the following results were reached:

- The results indicated that the extent of the commitment of Islamic banks to disclose social responsibility in the financial statements published in the city of Hebron was high according to the five-year scale. It agreed with the study of Zeinab Al-Nabulsi, 2018, the study of Mohamed Rahi, 2017, and it differed with the study of Al-Louh and Radi, 2016, in the presence of a disparity between banks in the disclosure of social responsibility, due to the fact that Islamic banks operating in the city of Hebron apply the disclosure of social responsibility according to From community service and the principles of Islamic law. The fourth study: a new study, Al-Azm, 2015, entitled: "Applying the reality of social responsibility in Jordanian banks and their impact on the competitive advantage from the viewpoint of workers in it."

- The results indicated that the degree of the Islamic banks 'contribution to Hebron City in various activities within its social responsibility came in a high degree according to the five-year scale, and it agreed with the study of Mohamed Rahi, 2017.

- The results indicated that the degree of Islamic banks in Hebron's disclosure of social responsibility activities in its financial statements came at a high level according to the five-year scale, and it agreed with a study (Song \&Shujie, $20 \mathrm{II})$ that there is a full disclosure of social activities in the financial statements of banks.

- The results indicated that the degree of obstacles to Islamic banks in the city of Hebron to disclose their activities in the areas of social responsibility came to a high degree and agreed with a study (Shruti, 20I4) in the presence of obstacles in the disclosure of social responsibility, which affects the financial position of banks.

\section{I0. Recommendations}

Based on the previous results, the research team recommends the following:

- The necessity of exerting more efforts in disclosing the social responsibility practices of Islamic banks, in order to build a good reputation for them towards their social role.

- Activating the role of organizations towards educating banks about the concept and importance of disclosing social responsibility.

- Banks make permanent and continuous communication with their customers and direct them towards the best methods, whether when providing banking services, or through projects related to the responsibilities of social banks.

- Providing training courses for workers in Islamic banks, to introduce them to the strategy of disclosing social responsibility and the importance of alerting it, as one of the strategies that contribute to achieving excellence in performance in general.

- The necessity for the Monetary Authority to issue special legislations related to the adoption of Islamic banks by disclosing their commitment to social responsibilities, given their implications for the performance of society.

- Conducting future studies related to the banks 'role in disclosing their social responsibilities.

\section{References}

Abu Jamea, N. (2016). The Role of Banks in Palestine Enriching Social Responsibility and its Reflection on its Financial Performance, Faculty of Administrative Sciences, Al-Azhar University, Gaza, Palestine.

Abu Nassar, M. (2010). International Accounting and Financial Reporting Standards, Wael Publishing and Distribution, Second Edition, Jordan.

Al-Ghabban, F. (20I0). Specialized Accounting Systems, Memory Library, Baghdad.

Al-Houry, F. (2014). Managing the mental image of Jordanian organizations in the context of social responsibility: a field study in Jordanian cellular communications companies, Amman, Jordan.

Al-Jazrawi, I. (2010). Basics of Accounting Information Systems, Al-Yazouri House for Publishing and Distribution, Jordan.

Al-Qadi, A. (2010). Social Responsibility of Banks Operating in Egypt as Egyptian Joint Stock Companies: Their Domains Their Impact on Performance, Egypt.

Al-Rubaie, H. (20I I). Banking Governance and its Impact on Performance and Risk, Al Yazouri Publishing and Distribution House, Amman.

Al-Sharah, R. (2014). Social Responsibility of Islamic Banks, A Case Study of Islamic Banks in Jordan, The Jordanian Journal of Islamic Studies, Amman, Jordan. 
Al-Trad, I. (20I I). Department of Local and International Banking Operations, Wael Publishing House, First Edition, Jordan.

Al-Zinati, O. (2014). The Role of Professional Ethics in Promoting Social Responsibility in Palestinian Governmental Hospitals (Al-Shifa Medical Complex), Academy of Management and Policy for Graduate Studies in partnership with the University of Jordan, The Jordanian Journal of Islamic Studies, Amman, Jordan.

Al-Zyoud, A. N. (2013). Social Responsibility of Banks Operating in Jordan (2008-2010), Management Science Studies, Jordan.

Amr, Y. (2010). Guide to Social Responsibility for Universities, Ramallah, Palestine.

Ayyash, M. (2010). Social Responsibility of Islamic Banks: Their Nature and Significance, Islamic Institute for Research and Training, Islamic Development Bank, Jeddah, Saudi Arabia.

Belal U. M. (20I0). Three Dimensional Aspects of Corporate Social Responsibility, Daffodil International University, Journal of Business and Economics, 3(I).

Bin Odeh, M. (201I). Social Responsibility of Private and Public Institutions and their Role in Achieving Sustainable Development, University of Jalaga, Algeria.

Bitar, M. (2012). Accounting Disclosure for Social Responsibility in Islamic Banks, World Islamic Economy Magazine, General Council of Islamic Banks and Financial Institutions, Islamic Transactions Research Center, Algeria.

Darmmon, Hanan, 2018, Evaluation of social responsibility practices in Islamic banks, an applied study on a sample of Islamic banks in Algeria, Setif University, Algeria.

Martinuzzi, A., Krumay, B., \& Pisano, U. (20II). Focus CSR: The new communication of the EU commission on CSR and national CSR strategies and action plans. European Sustainable Development Network (ESDN), Quarterly Report No, 23.

Rashi, T. (2013). The Role of Evoking the Social Responsibility Approach in Creating and Supporting Entrepreneurship and Competitiveness of Business Organizations, The Ninth International Scientific Conference on Islamic Economics and Finance, Istanbul, Turkey.

Saleh, S. (20I5). The Contribution of Social Responsibility in Promoting Competitive Advantage, Master Thesis, University of Mohamed Khader, Biskra, Algeria.

Yahyaoui, N. (20II). Sustainable Development and Social Responsibility from an Islamic Perspective, The Islamic Economy Forum: Reality and the Stakes of the Future, University of Ghardaia, Algeria.

Zouina, B. F. (2014). Bank Accounting Scheme between Theoretical Reference and Challenges of Implementation, Doctorate degree in Economic Sciences, Farhat Abbas University, Setif, Algeria.

\section{Copyrights}

Copyright for this article is retained by the author(s), with first publication rights granted to the journal. This is an open-access article distributed under the terms and conditions of the Creative Commons Attribution license (http://creativecommons.org/licenses/by/4.0/). 